\title{
Bilateral papilledema associated with spinal schwannoma
}

\section{Figure $1 \quad$ Papilledema}

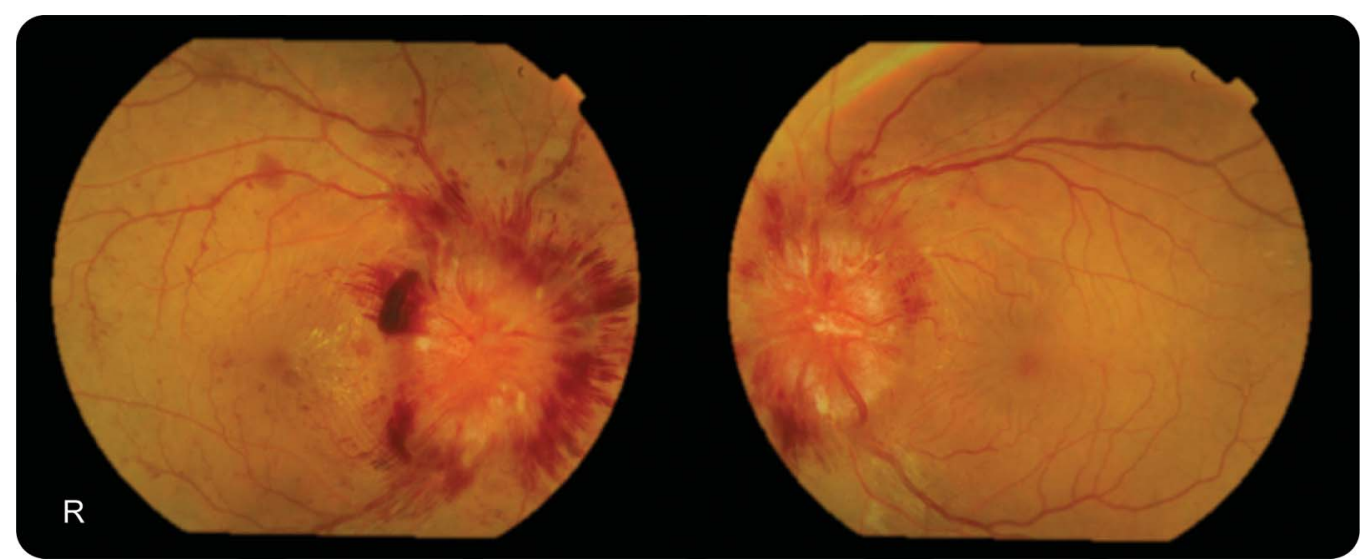

Funduscopy shows severe bilateral papilledema surrounded by peripapillary hemorrhage. Visual acuity was $20 / 50$ in both eyes.

A 61-year-old man presented with a 4-month history of progressive vision loss and paresthesia between the right L2-L4 dermatome. Funduscopy revealed severe bilateral papilledema (figure 1). Head CT showed mild hydrocephalus. CSF from a lumbar puncture at the L4-L5 level was xanthochromic with an elevated protein level (4,350 mg/dL). Lumbar spine MRI demonstrated a large intradural tumor at the L3-L4 level (figure 2), which was pathologically identified as schwannoma. Surgical removal resolved all symptoms. Papilledema is a rare complication induced by marked elevation of CSF protein, which may disturb CSF absorption and result in high intracranial pressure. ${ }^{1,2}$

Tomoyasu Matsubara, MD, Ayako Sakoda, MD, Yukimasa Arita, MD, Shuji Kanetou, MD, Takahisa Tateishi, MD, PhD, Nobuyoshi Takashima, MD, Kimiaki Hashiguchi, MD, PhD, Kei-ichiro Takase, $M D, P h D$

From Iizuka Hospital, Fukuoka, Japan.

Author contributions: T. Matsubara: drafting/revising the manuscript, acquisition of data, data analysis or interpretation of data. A. Sakoda: drafting/revising the manuscript, data analysis or interpretation of data. Y. Arita: drafting/revising the manuscript, data analysis or interpretation of data. S. Kanetou: drafting/revising the manuscript, acquisition of data, data analysis or interpretation of data. T. Tateishi: drafting/revising the manuscript, data analysis or interpretation of data. N. Takashima: drafting/revising the manuscript, data analysis or interpretation of data. K. Hashiguchi: operating surgeon. K.-i. Takase: drafting/revising the manuscript, acquisition of data, data analysis or interpretation of data, study supervision.

Study funding: No targeted funding reported.

Disclosure: The authors report no disclosures relevant to the manuscript. Go to Neurology.org for full disclosures.

Correspondence to Dr. Matsubara: tomoyasumatsubara@yahoo.co.jp

1. Oikawa S, Kyoshima K, Takemae T, Kobayashi S. Multiple spinal neurinomas presenting visual disturbance as the initial symptom: case report. Surg Neurol 1992;38:309-314.

2. Amlashi SF, Riffaud L, Morandi X. Communicating hydrocephalus and papilloedema associated with intraspinal tumours: report of four cases and review of the mechanisms. Acta Neurol Belg 2006;106:31-36. 
Figure 2 MRI of the spinal schwannoma

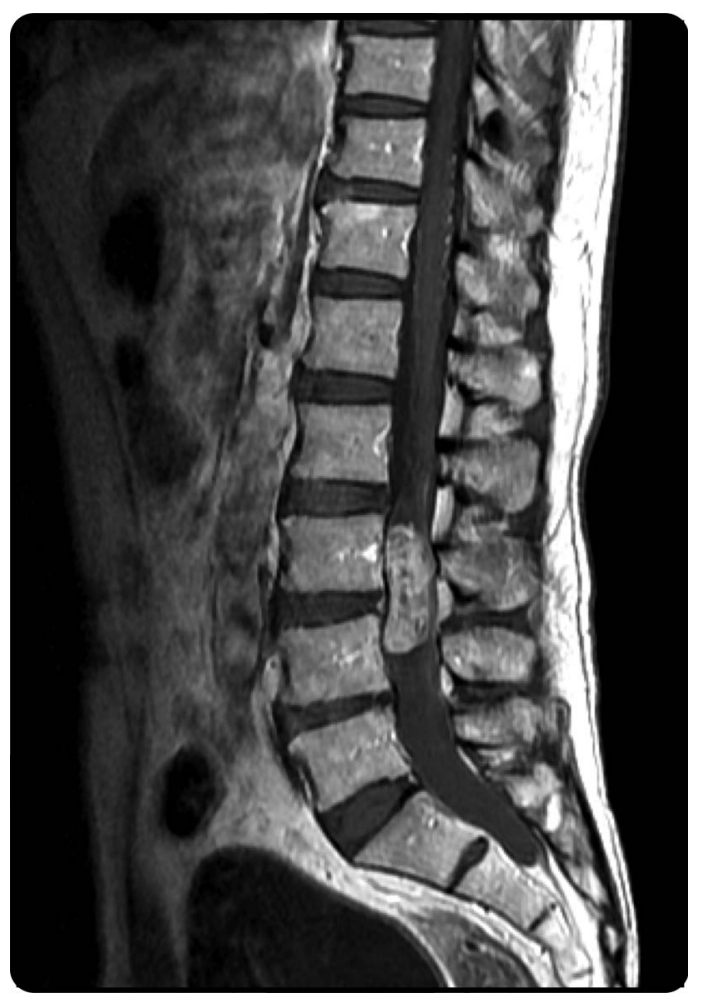

T1-weighted gadolinium-enhanced lumbar spine MRI demonstrates a heterogeneous hyperintense mass located in the vertebral canal at the level of the L3-L4 vertebral bodies.

\section{WriteClick ${ }^{\circledR}$ rapid online correspondence}

The editors encourage comments about recent articles through WriteClick:

Go to Neurology.org and click on the "WriteClick" tab at the top of the page. Responses will be posted within 72 hours of submission.

Before using WriteClick, remember the following:

- WriteClick is restricted to comments about studies published in Neurology within the last eight weeks

- Read previously posted comments; redundant comments will not be posted

- Your submission must be 200 words or less and have a maximum of five references; reference one must be the article on which you are commenting

- You can include a maximum of five authors (including yourself) 


\title{
Neurology
}

\author{
Bilateral papilledema associated with spinal schwannoma \\ Tomoyasu Matsubara, Ayako Sakoda, Yukimasa Arita, et al. \\ Neurology 2014;83;2312-2313 \\ DOI 10.1212/WNL.0000000000001065
}

This information is current as of December 8, 2014

\section{Updated Information \&} Services

\section{References}

Subspecialty Collections

Permissions \& Licensing

Reprints including high resolution figures, can be found at: http://n.neurology.org/content/83/24/2312.full

This article cites 2 articles, 0 of which you can access for free at: http://n.neurology.org/content/83/24/2312.full\#ref-list-1

This article, along with others on similar topics, appears in the following collection(s):

Cerebrospinal Fluid

http://n.neurology.org/cgi/collection/cerebrospinal_fluid

MRI

http://n.neurology.org/cgi/collection/mri

Retina

http://n.neurology.org/cgi/collection/retina

Spinal cord tumor

http://n.neurology.org/cgi/collection/spinal_cord_tumor

Information about reproducing this article in parts (figures,tables) or in its entirety can be found online at:

http://www.neurology.org/about/about_the_journal\#permissions

Information about ordering reprints can be found online:

http://n.neurology.org/subscribers/advertise

Neurology ${ }^{\circledR}$ is the official journal of the American Academy of Neurology. Published continuously since 1951, it is now a weekly with 48 issues per year. Copyright @ 2014 American Academy of Neurology. All rights reserved. Print ISSN: 0028-3878. Online ISSN: 1526-632X.

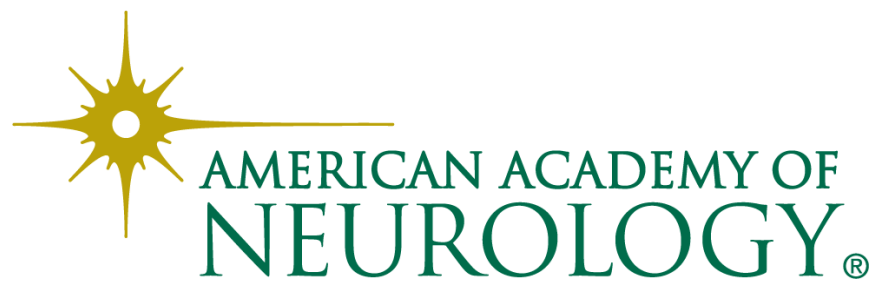

